\title{
MAPPING SOIL EROSION RISK IN RONDÔNIA, BRAZILIAN AMAZONIA: USING RUSLE, REMOTE SENSING AND GIS
}

\author{
D. LU, ${ }^{1} *$ G. LI, ${ }^{2}$ G. S. VALLADARES ${ }^{3}$ AND M. BATISTELLA ${ }^{3}$ \\ ${ }^{1}$ Center for the Study of Institutions, Population, and Environmental Change (CIPEC) Indiana University, Bloomington, IN, USA \\ ${ }^{2}$ Department of Geography, Geology, and Anthropology, Indiana State University, Terre Haute, IN, USA \\ ${ }^{3}$ Brazilian Agricultural Research Corporation, Embrapa Satellite Monitoring, Campinas, São Paulo, Brazil
}

Received 28 October 2003; Revised 22 March 2004; Accepted 1 April 2004

\begin{abstract}
This article discusses research in which the authors applied the Revised Universal Soil Loss Equation (RUSLE), remote sensing, and geographical information system (GIS) to the maping of soil erosion risk in Brazilian Amazonia. Soil map and soil survey data were used to develop the soil erodibility factor $(K)$, and a digital elevation model image was used to generate the topographic factor $(L S)$. The cover-management factor $(C)$ was developed based on vegetation, shade, and soil fraction images derived from spectral mixture analysis of a Landsat Enhanced Thematic Mapper Plus image. Assuming the same climatic conditions and no support practice in the study area, the rainfall-runoff erosivity $(R)$ and the support practice $(P)$ factors were not used. The majority of the study area has $K$ values of less than $0 \cdot 2, L S$ values of less than $2 \cdot 5$, and $C$ values of less than $0 \cdot 25$. A soil erosion risk map with five classes (very low, low, medium, medium-high, and high) was produced based on the simplified RUSLE within the GIS environment, and was linked to land use and land cover (LULC) image to explore relationships between soil erosion risk and LULC distribution. The results indicate that most successional and mature forests are in very low and low erosion risk areas, while agroforestry and pasture are usually associated with medium to high risk areas. This research implies that remote sensing and GIS provide promising tools for evaluating and mapping soil erosion risk in Amazonia. Copyright (C) 2004 John Wiley \& Sons, Ltd.
\end{abstract}

KEY WORDS: soil erosion risk; RUSLE; remote sensing; GIS; Brazilian Amazonia

\section{INTRODUCTION}

The adverse influences of widespread soil erosion on soil degradation, agricultural production, water quality, hydrological systems, and environments, have long been recognized as severe problems for human sustainability (Lal, 1998). However, estimation of soil erosion loss is often difficult due to the complex interplay of many factors, such as climate, land cover, soil, topography, and human activities. In addition to the biophysical parameters, social, economic, and political components also influence soil erosion (Ananda and Herath, 2003). Accurate and timely estimation of soil erosion loss or evaluation of soil erosion risk has become an urgent task.

Scientists have been involved in soil erosion research for a long time, and many models for soil erosion loss estimation have been developed (Wischmeier and Smith, 1978; Nearing et al., 1989; Adinarayana et al., 1999; D'Ambrosio et al., 2001; Veihe et al., 2001; Shen et al., 2003). Fullen (2003) summarized some keynote papers about soil erosion in northern Europe, and Lal (2001) highlighted major empirical models for predicting soil erosion loss. In practice, the Universal Soil Loss Equation (USLE) and later the Revised Universal Soil Loss

\footnotetext{
*Correspondence to: D. Lu, CIPEC_Indiana University, 408 N. Indiana Avenue, Bloomington, IN 47408, USA. E-mail: dlu@indiana.edu

Contract/grant sponsor: National Science Foundation, USA; contract/grant numbers: 95-21918 and 99-06826.

Contract/grant sponsor: National Aeronautics and Space Administration, USA; contract/grant number: N005-334.

Contract/grant sponsor: Embrapa Satellite Monitoring, Brazil.
}

Copyright (C) 2004 John Wiley \& Sons, Ltd. 
Equation (RUSLE) has been the most widely used model in predicting soil erosion loss. The USLE was originally developed for soil erosion estimation in croplands on gently sloping topography (Wischmeier and Smith, 1978). The RUSLE has broadened its application to different situations, including forest, rangeland, and disturbed areas (Renard et al., 1997). Traditionally, these models were used for local conservation planning at an individual property level. The factors used in these models were usually estimated or calculated from field measurements. The methods of quantifying soil loss based on erosion plots possess many limitations in terms of cost, representativeness, and reliability of the resulting data. They cannot provide spatial distribution of soil erosion loss due to the constraint of limited samples in complex environments. So, mapping soil erosion in large areas is often very difficult using these traditional methods.

The use of remote sensing and geographical information system (GIS) techniques makes soil erosion estimation and its spatial distribution feasible with reasonable costs and better accuracy in larger areas (Millward and Mersey, 1999; Wang et al., 2003). For example, a combination of remote sensing, GIS, and RUSLE provides the potential to estimate soil erosion loss on a cell-by-cell basis (Millward and Mersey, 1999). Boggs et al. (2001) assessed soil erosion risk based on a simplified version of RUSLE using digital elevation model (DEM) data and land-units maps. Bartsch et al. (2002) used GIS techniques to interpolate RUSLE parameters for sample plots to determine the soil erosion risk at Camp Wiliams, Utah. Wilson and Lorang (2000) reviewed the applications of GIS in estimating soil erosion, discussed the difficulty and limitations of previous research and identified that GIS provided tremendous potential for improving soil erosion estimation. Wang et al. (2003) used a sample ground dataset, Thematic Mapper (TM) images, and DEM data to predict soil erosion loss through geostatistical methods (i.e., collocated cokriging and a joint sequential cosimulation model). They showed that such methods provided significantly better results than using traditional methods. In general, remote-sensing data were primarily used to develop the cover-management factor image through land-cover classifications (Millward and Mersey, 1999; Reusing et al., 2000; Ma et al., 2003), while GIS tools were used for derivation of the topographic factor from DEM data, data interpolation of sample plots, and calculation of soil erosion loss (Cerri et al., 2001; Bartsch et al., 2002; Wang et al., 2003).

In many situations, land managers and policy makers are more interested in the spatial distribution of soil erosion risk than in absolute values of soil erosion loss. Different approaches have been used to assess the soil erosion risk, including empirical erosion models (Boggs et al., 2001; Cerri et al., 2001; Bartsch et al., 2002), a ranking method based on selected indicators such as percentage of bare ground, aggregate stability, organic carbon, percentage clay, and bulk density (Shakesby et al., 2002), and qualitative erosion risk mapping based on the combination of five factors (geology, soil, relief, climate, and vegetation) (Vrieling et al., 2002).

Brazilian Amazonia has experienced high deforestation rates since the 1970s, with large areas of mature forest being converted to patches of different successional stages, agricultural lands, and pastures (Batistella et al., 2003). The deforestation has been recognized as a major cause of soil degradation through soil erosion and the changes in important climate and ecosystem components (Thiam, 2003). However, the evaluation of soil erosion risk within Brazilian Amazonia has not attracted sufficient scientific attention. This article explores this topic using a simplified RUSLE based on the integration of remote sensing and GIS in the moist tropical region of the Brazilian Amazonia and examines the relationships between land use and land cover (LULC), and soil erosion risks.

\section{BRIEF DESCRIPTION OF THE RUSLE}

The RUSLE represents how climate, soil, topography, and land use affect rill and interrill soil erosion caused by raindrop impact and surface runoff (Renard et al., 1997). It has been extensively used to estimate soil erosion loss, to assess soil erosion risk, and to guide development and conservation plans in order to control erosion under different land-cover conditions, such as croplands, rangelands, and disturbed forest lands (Millward and Mersey, 1999; Boggs et al., 2001; Mati and Veihe, 2001; Angima et al., 2003). The RUSLE is expressed as:

$$
A=R K L S C P
$$


Table I. Summary of main methods for developing RUSLE parameters

\begin{tabular}{|c|c|c|}
\hline & Methods & References \\
\hline \multirow[t]{6}{*}{$R$} & Using erosion index values for all rainfall storms in one year & Wischmeier and Smith, 1978 \\
\hline & Using average monthly precipitation and average annual precipitation & Renard and Fremund, 1994 \\
\hline & Using a regression model based on measured annual precipitation & Millward and Mersey, 1999 \\
\hline & $\begin{array}{l}\text { Using a regression model of the } R \text { factor with average annual } \\
\text { precipitation and elevation data }\end{array}$ & Mikhailova et al., 1997 \\
\hline & Using geostatistical methods such as kriging estimators & Goovaerts, 1999 \\
\hline & Using simulation techniques such as sequential Gaussian simulation & Wang et al., 2002a \\
\hline \multirow[t]{5}{*}{$K$} & $\begin{array}{l}\text { Using the experimental models based on soil properties (composition } \\
\text { of sand-silt-clay percentages, organic matter, structure, and } \\
\text { permeability of the soil profile) }\end{array}$ & Wischmeier and Smith, 1978 \\
\hline & $\begin{array}{l}\text { Using regression equation based on soil properties (percentages of } \\
\text { unstable aggregates, silt, sand, and base saturation) }\end{array}$ & Angima et al., 2003 \\
\hline & Using the published $K$ values by USDA-NRCS & Soil Survey Staff, 1997 \\
\hline & Based on size of soil particulates & Romken, 1983 \\
\hline & $\begin{array}{l}\text { Using geostatistical methods such as joint sequential simulation and } \\
\text { sequential Gaussian simulation }\end{array}$ & $\begin{array}{l}\text { Parysow et al., } 2003 \text {, } \\
\text { Wang et al., } 2001\end{array}$ \\
\hline \multirow[t]{2}{*}{$L S$} & Estimated from actual field measurements of length and steepness & Wischmeier and Smith, 1978 \\
\hline & Calculated from DEM data with various approaches & Hickey, 2000; Van Remortel et al., 2001 \\
\hline \multirow[t]{5}{*}{$C$} & $\begin{array}{l}\text { Using individual soil-loss ratio values and the factor of rainfall and } \\
\text { runoff erosivity }\end{array}$ & Renard et al., 1997 \\
\hline & $\begin{array}{l}\text { Combination of individual } C \text { factor from empirical models and } \\
\text { remote-sensing classification image }\end{array}$ & Millward and Mersey, 1999 \\
\hline & $\begin{array}{l}\text { From supervised land-cover classification of multispectral } \\
\text { MOMS-02/D2 data }\end{array}$ & Reusing et al., 2000 \\
\hline & Geostatistical techniques & Wang et al., 2002b \\
\hline & Greenness index & Ma et al., 2003 \\
\hline$P$ & Experimental data & Renard et al., 1997 \\
\hline
\end{tabular}

where $A$ is the average annual soil loss in tons per acre; $R$ is the rainfall-runoff erosivity factor; $K$ is the soil erodibility factor; $L$ is the slope length factor; $S$ is the slope steepness factor; $C$ is the cover-management factor; and $P$ is the support practice factor. Table I summarizes the main methods for estimating these factors. Previous literature has described these methods extensively.

\section{STUDY AREA}

Rondônia has experienced high deforestation rates during the past two decades (INPE, 2002). Following the national strategy of regional occupation and development, colonization projects initiated by the Brazilian Government in the 1970s played a major role in this process (Moran, 1981). The colonists transformed the forested landscape into a patchwork of cultivated crops, pastures, successional vegetation, and remnant forests (Batistella, 2001).

The study area is located at Machadinho d'Oeste, in northeastern Rondônia (Figure 1). The climate in this study area is classified as equatorial hot and humid with tropical transition. A well-defined dry season lasts from June to August, and the annual average precipitation is $2016 \mathrm{~mm}$ (Rondônia, 1998). The annual average temperature is $25.5^{\circ} \mathrm{C}$, and monthly averages for air moisture range from 80 to 85 per cent. The terrain is undulating, ranging from 100 to $400 \mathrm{~m}$ above sea-level. Several soil types were identified, mainly alfisols, oxisols, ultisols, alluvial soils, and other less spatially represented associations (Bognola and Soares, 1999; Valladares et al., 2003). 


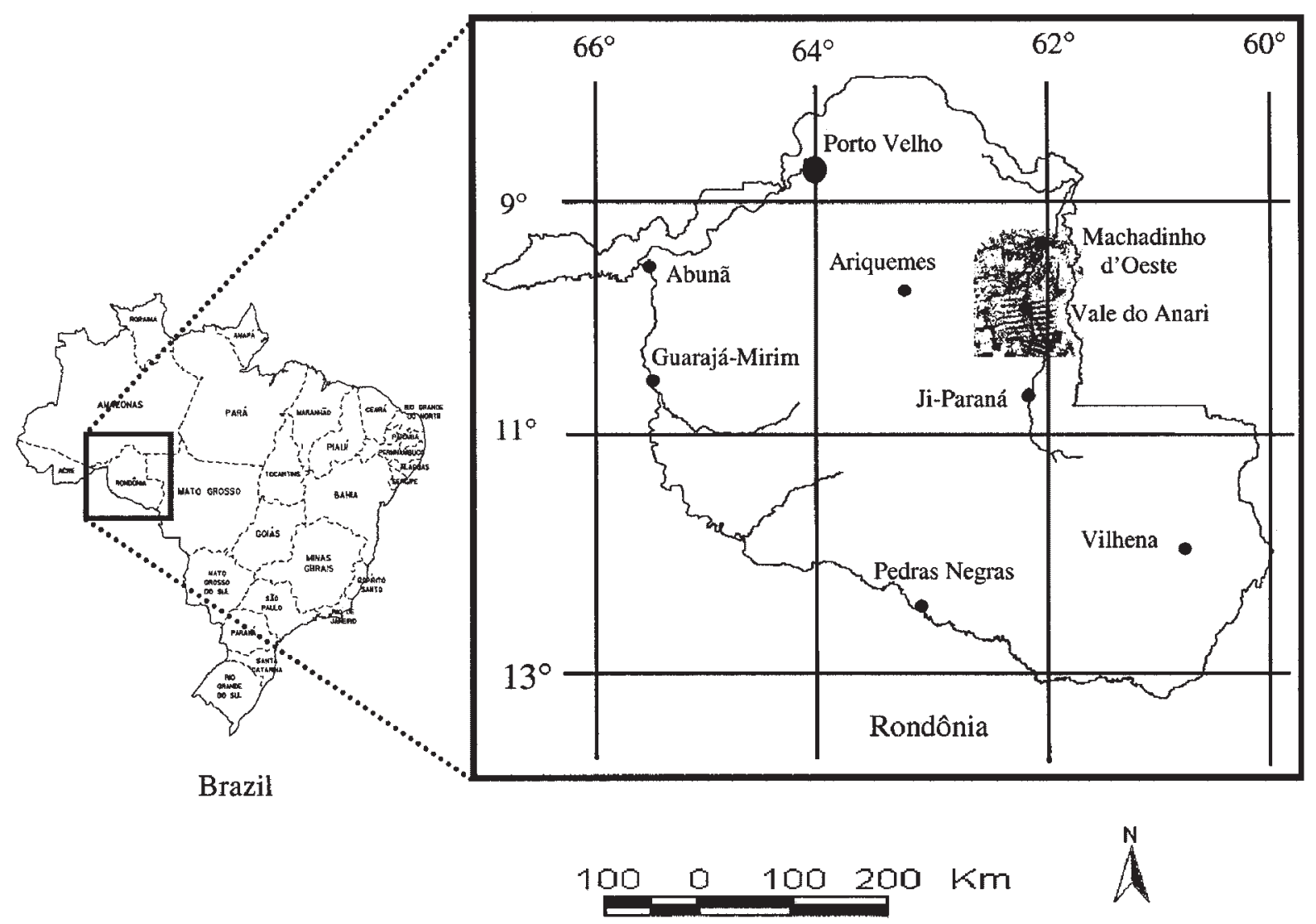

Figure 1. Location of the study area in the State of Rondônia, Brazilian Amazonia.

\section{DATA PREPARATION}

Landsat 7 ETM+ (path/row: 231/67) was acquired on 27 June 2002. The image was converted to apparent reflectance through an image-based calibration method using the gain, offset, and sun elevation angle (Markam and Barker, 1987). This image was also geometrically rectified using control points collected from topographic maps so that the image can be accurately linked to ground reference data and other ancillary data, such as soil type map and DEM data. The nearest-neighbor resampling technique was used and a root-mean-square error with less than $0 \cdot 5$ pixels was obtained during the image geometric rectification.

Field data collection was conducted in August 2002. Different LULC types, such as mature forest, successional forest, agroforestry (mainly coffee plantations), and pasture, were identified and their coordinates were recorded with a GPS device. These data were used as training samples for supervised classification of ETM+ data. About 10 to 15 sample plots for each class were selected. Maximum likelihood classifier (MLC) was used to classify the ETM+ data into six LULC classes: mature forest; successional forest; agroforestry; pasture; urban; and water. A majority filter with a $3 \times 3$ window size was used to remove the 'salt and pepper' noise in the classified image. Accuracy assessment using field data collected in August 2003 indicated an overall accuracy of approximately 90 per cent. Figure 2 shows the LULC distribution within the study area. A detailed description of LULC classification using MLC can be found in Lu et al. (2004).

The soil map was generated in 2003 based on interpretation of landforms and pedoforms within the landscape using Landsat TM data and aerial photographs, corroborated by soil field surveys. The representative soil profile samples were collected, described, and characterized according to the Soil Survey Manual (Soil Survey Staff, 


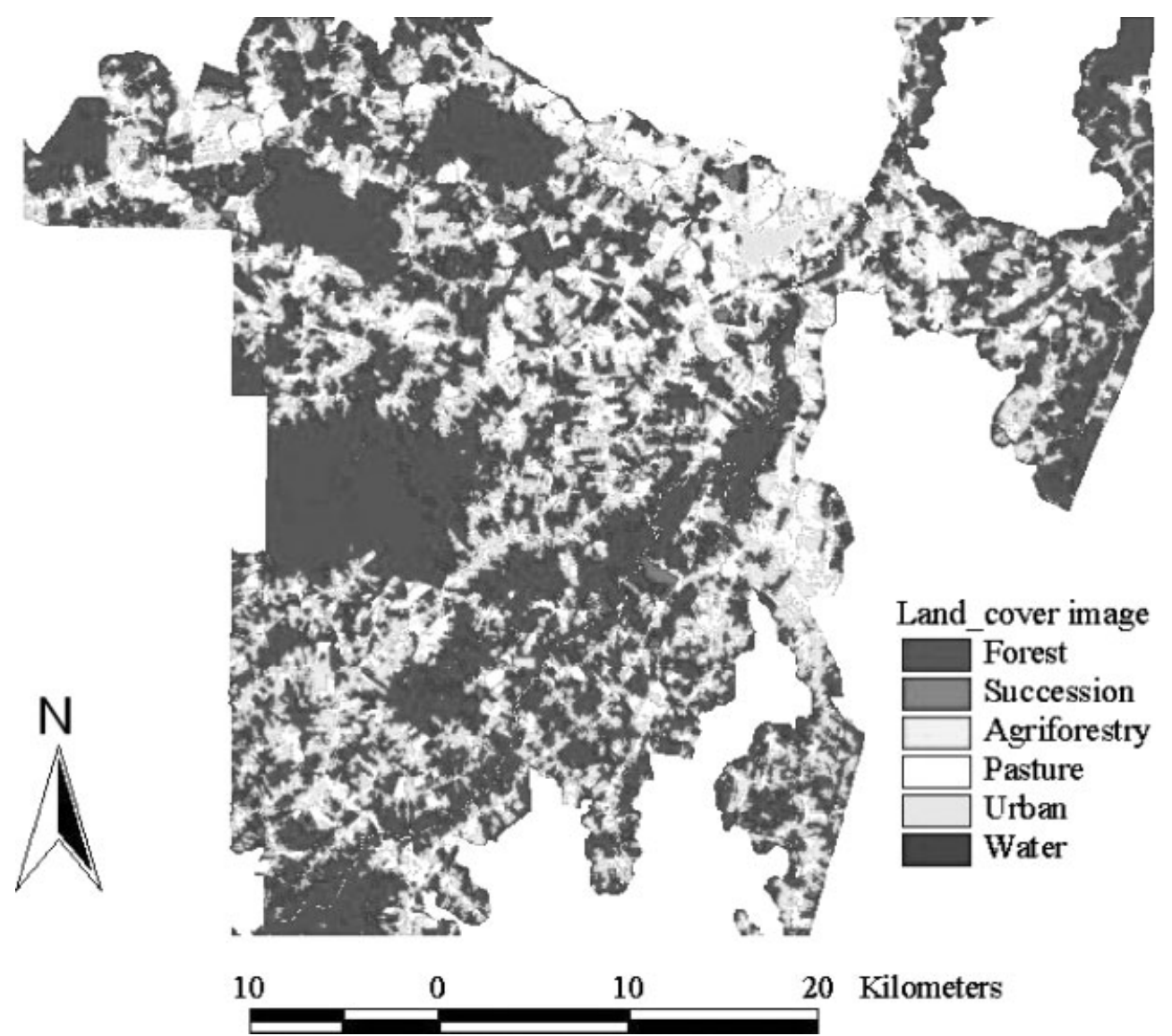

Figure 2. Land-use and land-cover classification for the study area based on ETM+ data.

1993), Lemos and Santos (1996), and Embrapa (1999). The soil types were classified according to Soil Taxonomy (Soil Survey Staff, 1998, 1999). A more detailed description of the soils in this study area can be found in Valladares et al. (2003) and in Embrapa (1999). Figure 3 illustrates the distribution of soil types in this study area.

Fieldwork for collecting soil sample plots was conducted in September 2002. A total of 22 samples were collected in representative points of the study area based on relief, soil, and land-cover (Valladares et al., 2003). During fieldwork, the position on the relief, morphologic description, color, structure, consistency, texture, and other parameters, were recorded. In the lab, soil $\mathrm{pH}, \mathrm{CaCl}_{2}$, content of $\mathrm{Ca}, \mathrm{Mg}, \mathrm{K}, \mathrm{Na}, \mathrm{H}, \mathrm{Al}$, sum of bases, cation exchange capacity, $\mathrm{P}$, organic carbon, clay, silt, and sand were analyzed. The sampling strategy was based on the representativeness of the soil's orders and suborders occurring in the study area (Soil Survey Division Staff, 1993; Lemos and Santos, 1996; Embrapa, 1999).

Contour lines, rivers, and typical points were digitized based on 1:100 000 topographic maps (UTM, South American, Zone 20), then a 30-meter spatial resolution DEM was generated using ArcGIS. Figures 4 and 5 illustrate the elevation and slope distribution for the study area. Most elevations are between 100 and $300 \mathrm{~m}$ and are associated with gentle slopes (less than 5 degrees).

\section{EVALUATION OF THE SOIL EROSION RISK}

Six parameters are required for the soil erosion estimation, as described previously. Because this study focuses on the evaluation of soil erosion risk, instead of estimation of actual soil erosion loss, the $R$ and $P$ factors were not 


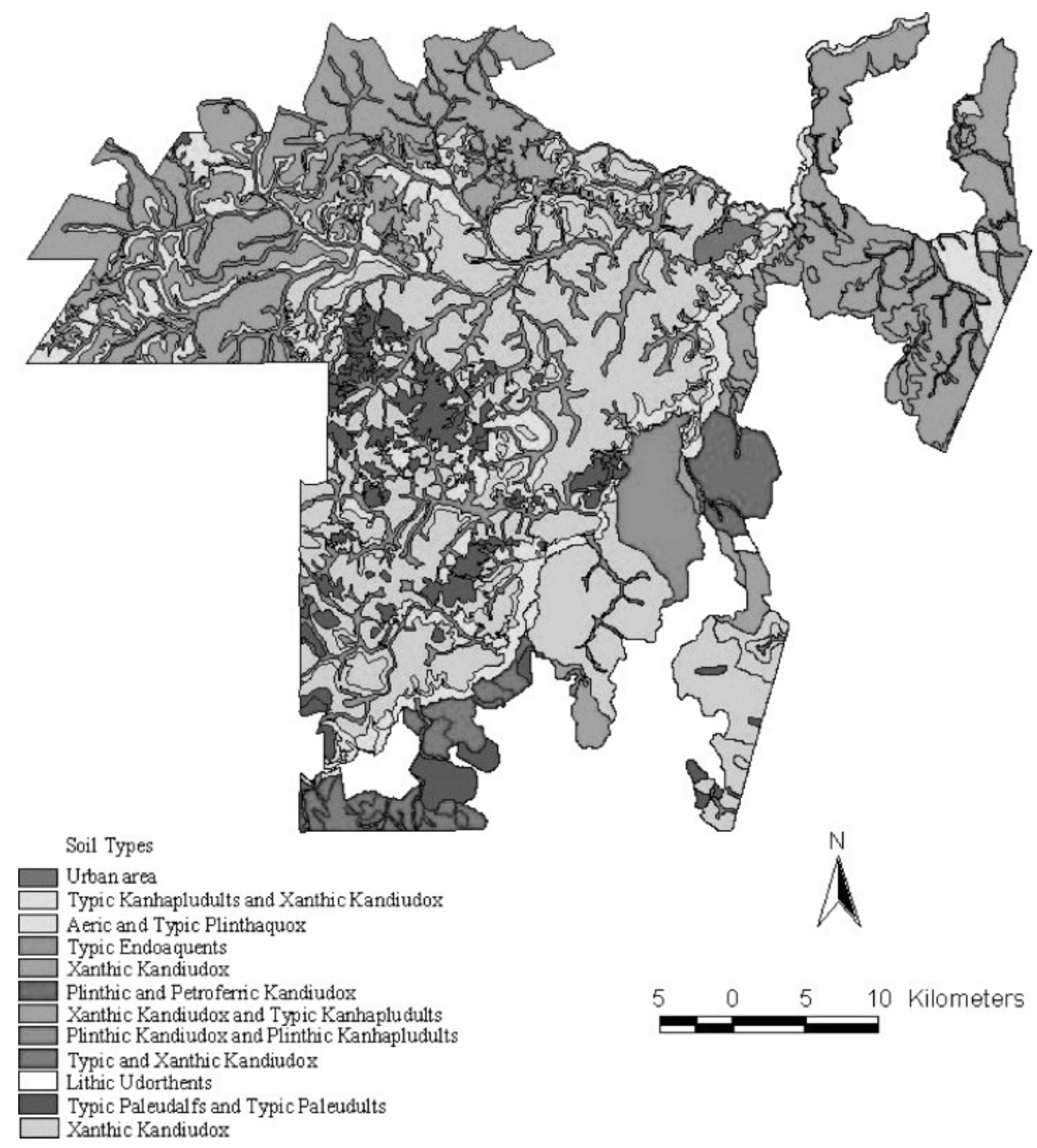

Figure 3. Spatial distribution of soil types within the study area.

used, assuming that same climatic conditions and no support practices existed within the study area. So the soil erosion risk (SER) was developed based on $K, L S$, and $C$ factors in a simplified equation: $S E R=K L S C$.

\section{Development of the K Factor Image}

The $K$ factor is related to the integrated effects of rainfall, runoff, and infiltration on soil loss, accounting for the influences of soil properties on soil loss during storm events on upland areas (Renard et al., 1997). It is often 


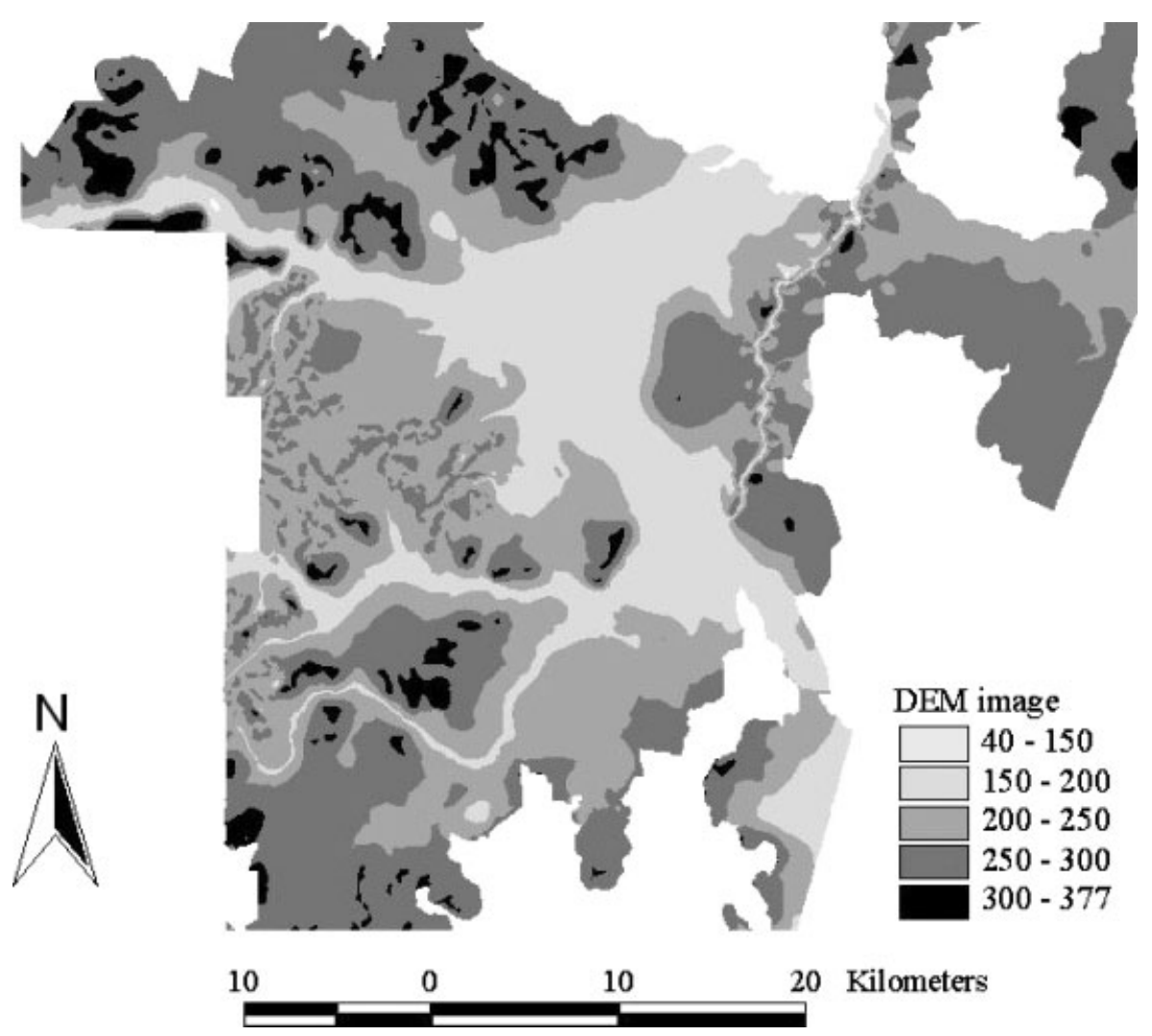

Figure 4. Grey-scale image illustrating elevation classes within the study area.

estimated through experimental equations (e.g., Equation 2) or corresponding nomographs (Wischmeier and Smith, 1978).

$$
K=2 \cdot 1 \times 10^{-6} \times M^{1 \cdot 14} \times(12-O M)+0 \cdot 0325 \times(P-2)+0 \cdot 025 \times(S-3),
$$

where $M=(\%$ silt $+\%$ very_fine_sand $)(100-\%$ clay $) ; O M=$ percentage of organic matter; $P=$ permeability class; and $S=$ structure class.

The $K$ value for each sample plot was calculated, then each soil type was associated with a $K$ value assuming that the same soil type has the same $K$ value throughout the study area. Figure 6 illustrates the $K$ factor distribution. It indicates that most of the study area has a $K$ value of less than $0 \cdot 2$.

\section{Development of the LS Factor Image}

The $L S$ factor accounts for the effect of topography on erosion in RUSLE. The slope length factor $(L)$ represents the effect of slope length on erosion, and the slope steepness factor $(S)$ reflects the influence of slope gradient on erosion. The common equation used for calculating $L S$ is an empirical equation (see Equation 3) provided by the USDA Agriculture Handbook (Wischmeier and Smith, 1978).

$$
L S=\left(\frac{\lambda}{22 \cdot 13}\right)^{n}\left(65 \cdot 41 \sin ^{2} \theta+4 \cdot 56 \sin \theta+0 \cdot 065\right),
$$




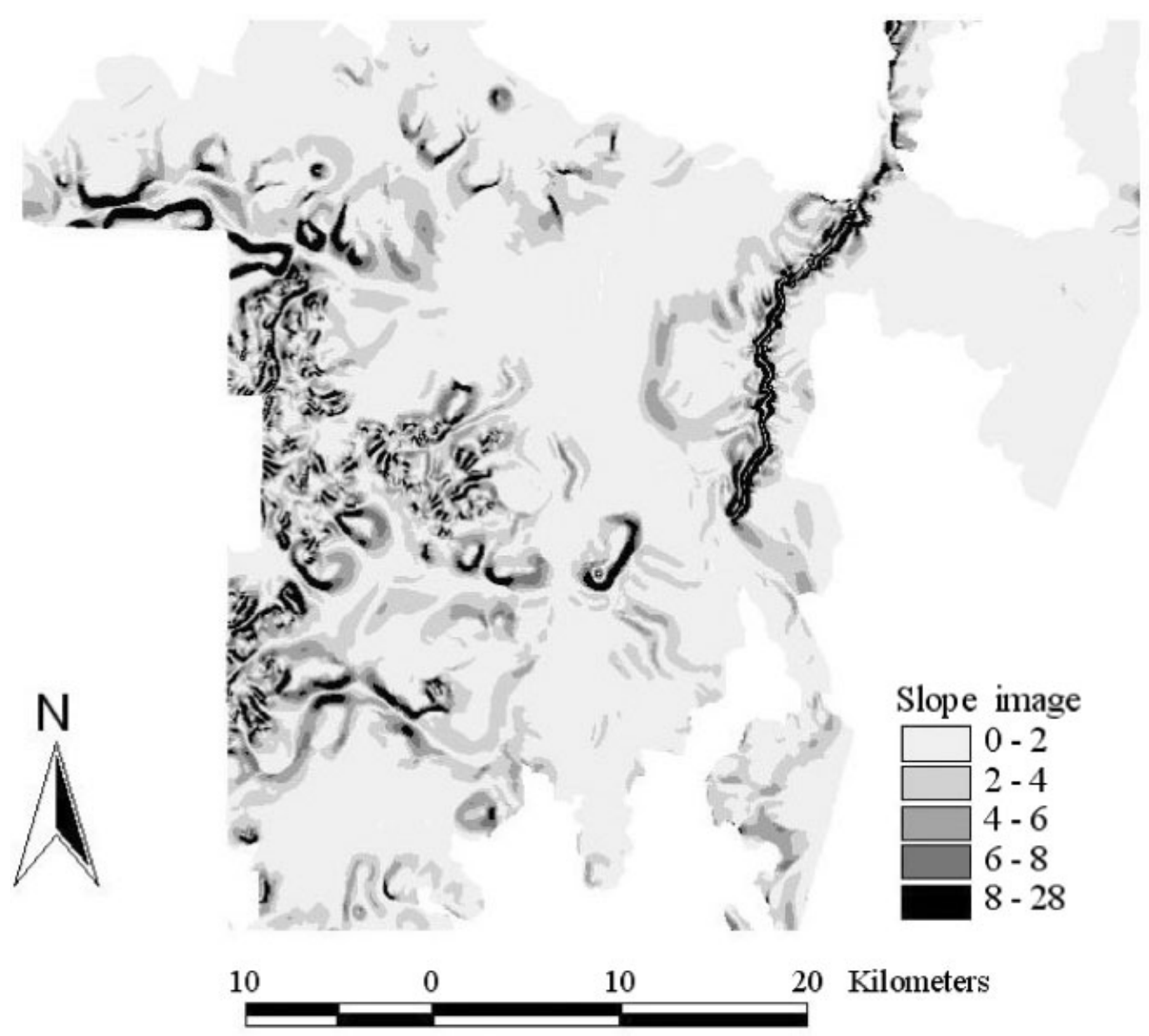

Figure 5. Grey-scale image illustrating slope classes within the study area.

where $\lambda$ is the slope length in meters; $\theta$ is the angle of slope in degrees; and $n$ is a constant dependent on the value of the slope gradient: 0.5 if the slope angle is greater than 2.86 degrees, 0.4 on slopes of 1.72 to 2.85 degrees, 0.3 on slopes of 0.57 to 1.72 degrees, and 0.2 on slopes less than 0.57 degrees.

The RUSLE-based ArcInfo Arc Macro Language (AML) program for computing the $L S$ factor was developed using the raster grid cumulation and maximum downhill slope methods (Hickey, 2000; Van Remortel et al., 2001) and is available at the following website: www.cwu.edu/ rhickey/slope/slope.html. Figure 7 illustrates the $L S$ factor distribution. It indicates that the majority of the study area has $L S$ values of less than $2 \cdot 5$. Some specific areas with steep slopes, such as along the river, have $L S$ values of greater than $2 \cdot 5$.

\section{Development of the C Factor Image}

The $C$ factor reflects the effects of cropping and management practices on soil erosion rates in agricultural lands and the effects of vegetation canopy and ground covers on reducing the soil erosion in forested regions (Renard et al., 1997). Usually, the $C$ factor is derived using empirical equations based on the measurements of many variables related to ground covers collected in the sample plots. The $C$ factor values at non-sampled locations were estimated through spatial interpolation techniques. This method is often time-consuming and computer intensive. It only provides point values with limited locations. The interpolation results based on the $C$ factor point values 


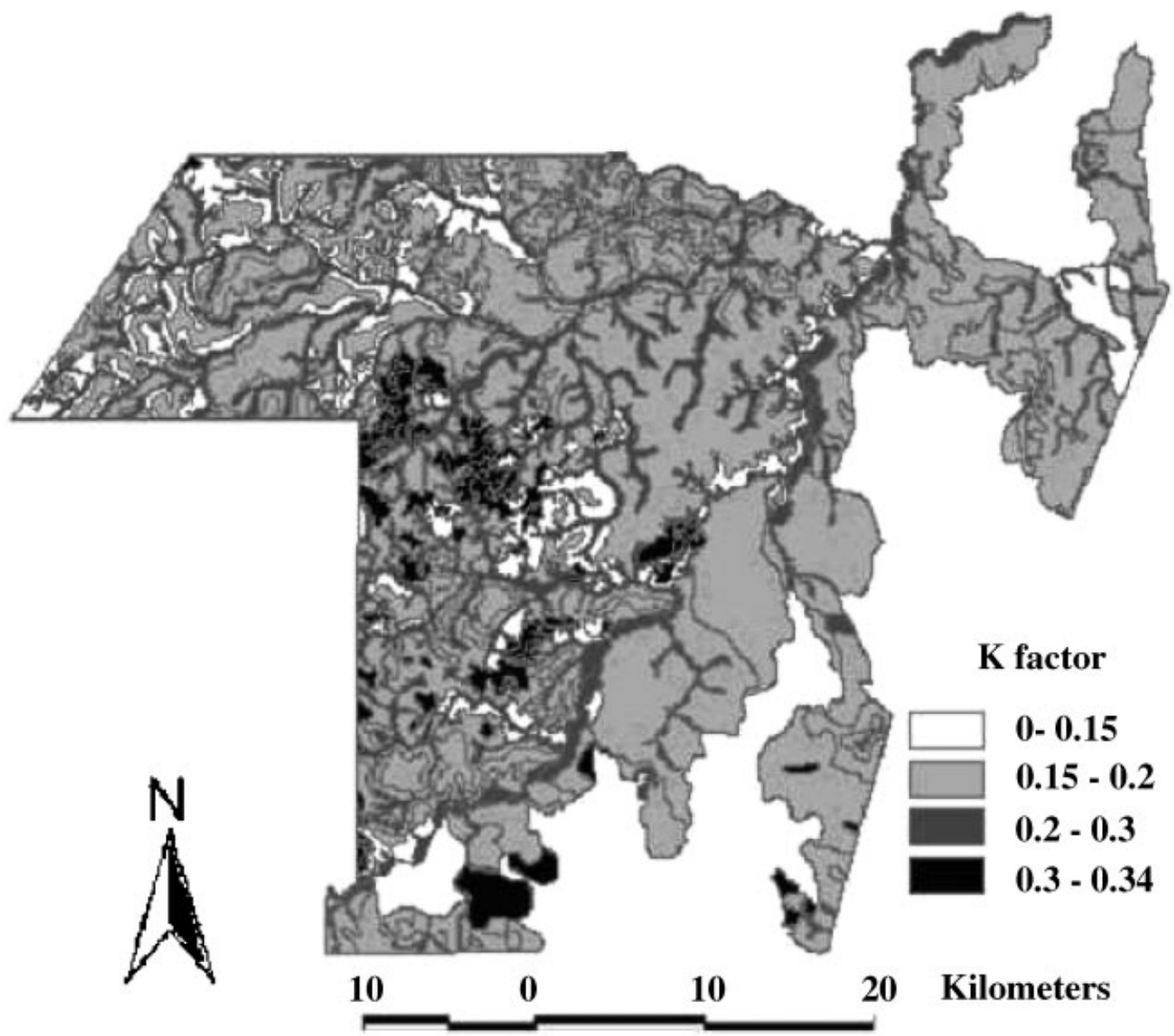

Figure 6. The soil erodibility factor developed from soil sample plots data and soil map.

could be poor due to the limited number of sample plots in complex environments (Wang et al., 2002b). Therefore, remotely sensed data have been used to estimate the $C$ factor distribution based on land-cover classification results (Millward and Mersey, 1999; Reusing et al., 2000), assuming that the same land covers have the same $C$ factor values. The result greatly depends on: (1) the details of land-cover classes and classification accuracy; and (2) the determination of a suitable $C$ factor value for each class. However, the same land-cover class may have different $C$ factors due to variations in vegetation density.

In this study, the $C$ factor was estimated (see Equation 4) based on the fraction images from spectral mixture analysis (SMA) of Landsat ETM+ image, assuming that abundant vegetation cover associated with a complex stand structure results in less soil erosion loss, while more soil fraction associated with less vegetation cover results in higher soil erosion loss.

$$
C=\frac{f_{\text {soil }}}{1+f_{\mathrm{gv}}+f_{\text {shade }}+f_{\mathrm{gv}} \times f_{\text {shade }}},
$$

where $f_{\text {soil }}, f_{\mathrm{gv}}$, and $f_{\text {shade }}$ are the three fraction values of soil, green vegetation, and shade endmembers. The values of $f_{\text {soil }}, f_{\mathrm{gv}}$, and $f_{\text {shade }}$ parameters range from 0 to 1 and their sum equals 1 . A detailed description of SMA can be 


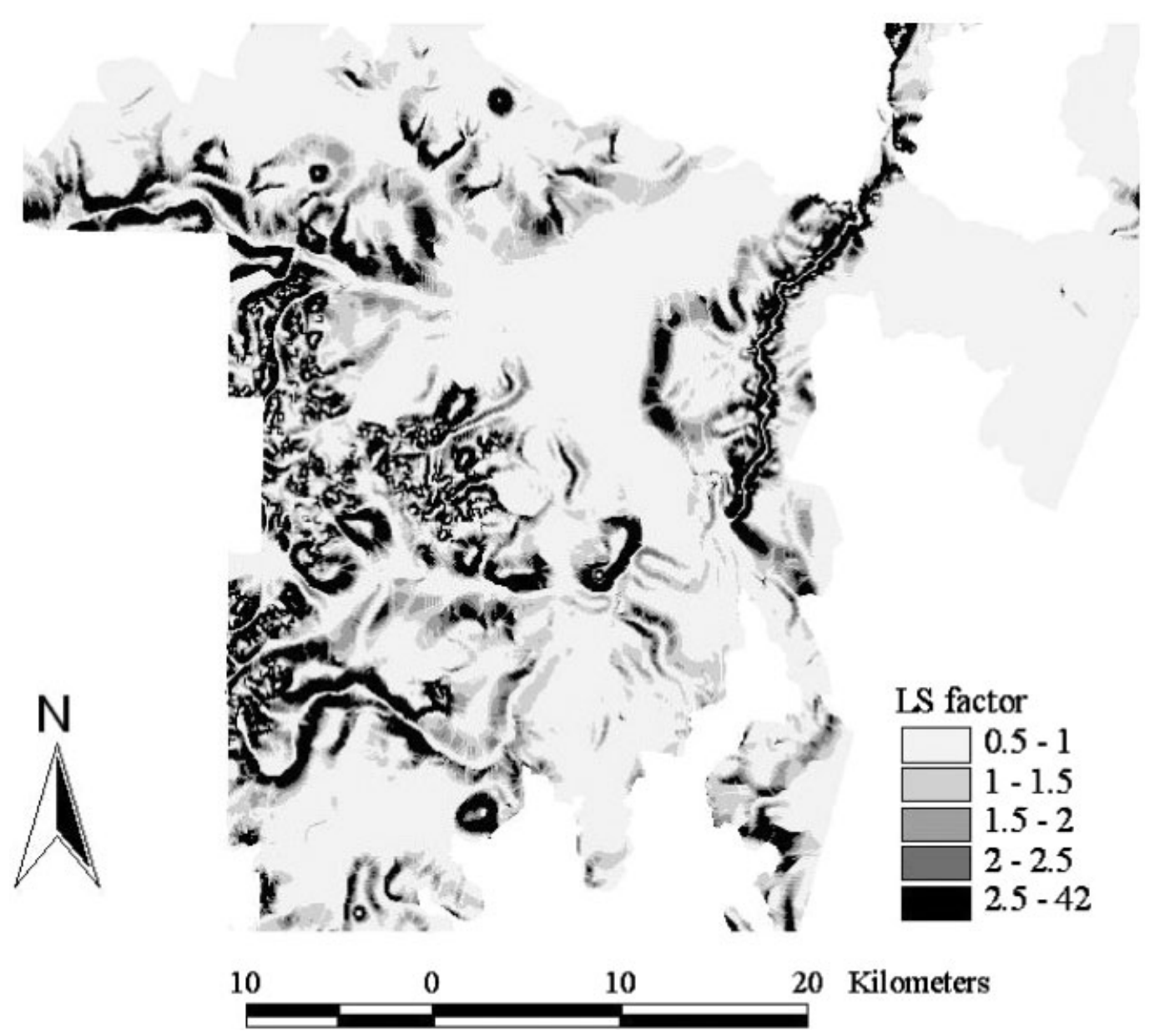

Figure 7. The topographic factor developed from the DEM data.

found in Lu et al. (2003). Figure 8 illustrates the $C$ factor distribution. The majority of the study area has $C$ values of less than $0 \cdot 25$. Very few areas have $C$ values greater than $0 \cdot 5$.

\section{Development of the Soil Erosion Risk Image}

After the $K, L S$, and $C$ factor images were developed, they were overlaid using GIS tools to generate the SER image. Five risk levels, i.e., very low, low, medium, medium-high, and high, were identified and mapped (Figure 9). The majority of the study area has very low and low risk levels. Very few areas fall in medium-high and high risk levels.

\section{Relating the LULC Image and the SER Image}

A linkage between the LULC and the SER images is valuable for understanding how different LULC classes affect soil erosion. The LULC classes were recorded as 1, 2, 3, 4, and 5, corresponding to forest, successional forest, agroforestry, pasture, and others (urban and water), respectively. The SER image was also recorded as 1, 2, 3, 4 and 5 corresponding to very low, low, medium, medium-high, and high levels, respectively. These two images were compared pixel by pixel to generate a table indicating the relationship of LULC and SER classes. Table II provides the percentage of SER with LULC classes. It indicates that mature forest, most successional forests and 


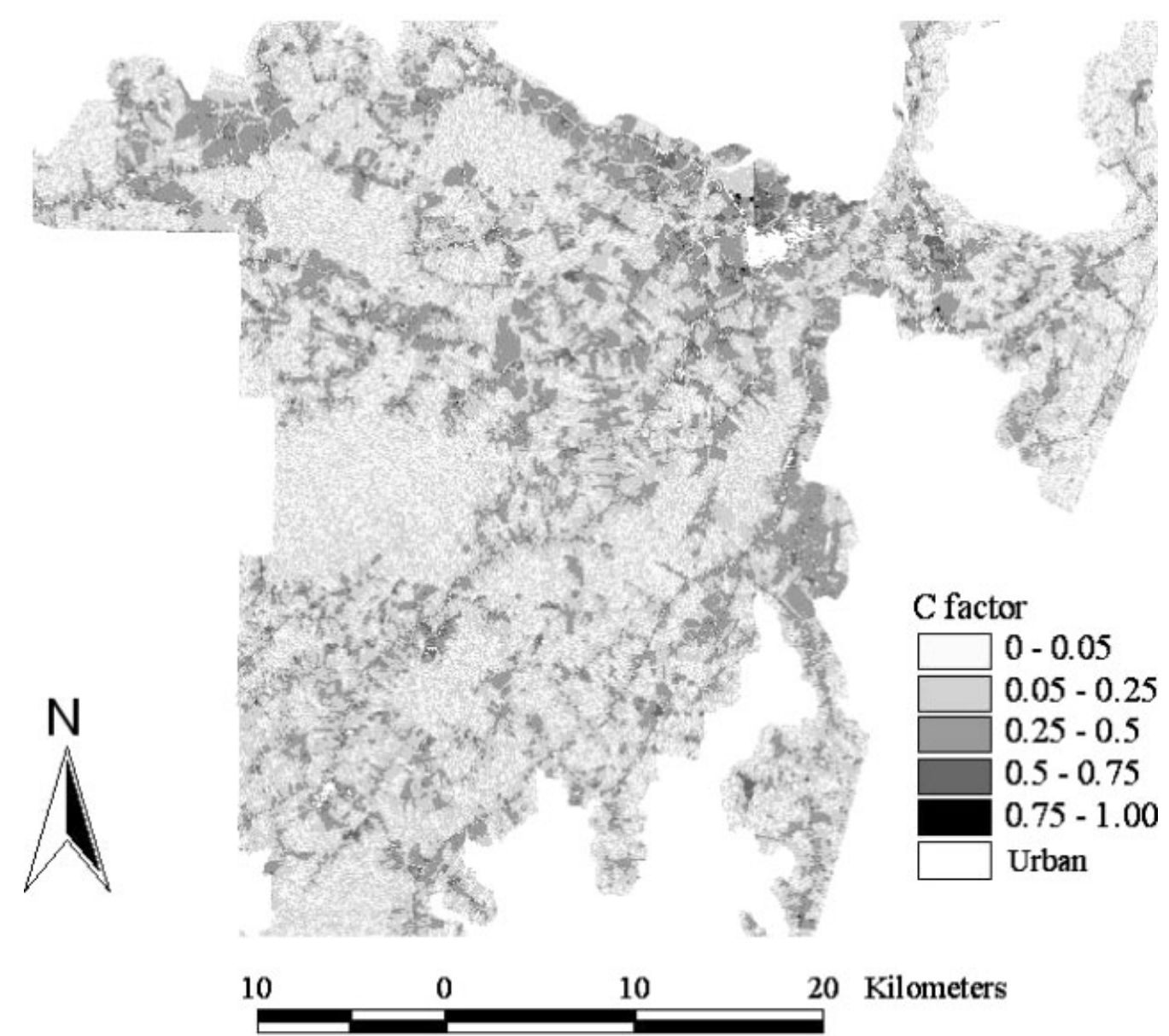

Figure 8. The cover-management factor developed using vegetation, shade, and soil fractions of ETM + data.

agroforestry have very low or low erosion risks, but some of the pasture and agroforestry areas with limited ground cover have medium-high or high erosion risks. Table II also shows that very few areas of mature forest had medium or medium-high erosion risk. These pixels were located at the juncture of mature forests and other land covers due to the misregistration between ETM+, DEM, and soil data.

\section{DISCUSSION AND CONCLUSIONS}

RUSLE was originally developed for the USA, but also has been proven valuable for estimation of soil erosion loss in other regions of the world (Millward and Mersey, 1999; Reusing et al., 2000; Angima et al., 2003, Ma et al., 2003). In general, RUSLE is used for estimating average annual soil erosion loss based on sample plot data. The use of remote sensing and GIS allows us to map the spatial distribution of soil erosion risk. However, because remotely sensed data capture the surface characteristics at the time of the image acquisition, caution must be taken when developing the $C$ factor image. Calibration of the results using reference data may be necessary if it is used for estimation of absolute soil erosion loss. Also, the use of multitemporal remotely sensed data may be necessary to generate an average $C$ factor image.

Six parameters, derived from different data sources such as DEM, soil, climate, and remotely sensed data, are used in the RUSLE. The different data sources may have different data formats, projections, data quality, and 


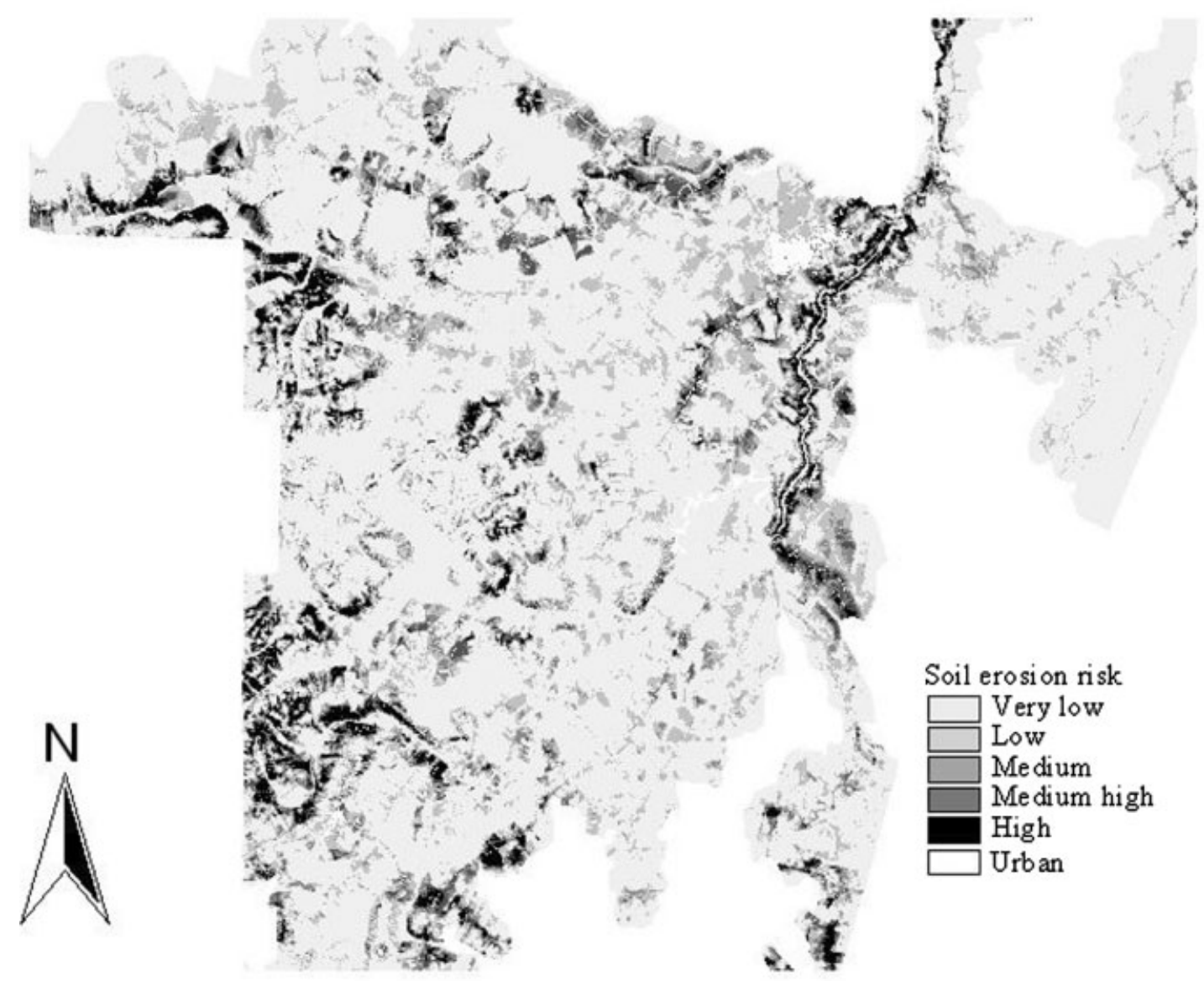

10 0 10 20 Kilometers

Figure 9. Erosion risk image illustrating the soil erosion conditions within the study area.

Table II. Assessment of soil erosion risk and associated land-cover distribution

\begin{tabular}{|c|c|c|c|c|c|c|}
\hline \multirow[t]{2}{*}{ LULC type } & \multicolumn{5}{|c|}{ Soil erosion risk } & \multirow[t]{2}{*}{ Total (\%) } \\
\hline & Very low $(\%)$ & Low (\%) & Medium (\%) & Medium-high (\%) & High (\%) & \\
\hline Forest & $43 \cdot 30$ & $2 \cdot 53$ & 0.87 & 0.52 & $0 \cdot 31$ & 47.53 \\
\hline Succession & $9 \cdot 05$ & 0.94 & $0 \cdot 31$ & $0 \cdot 19$ & $0 \cdot 15$ & $10 \cdot 64$ \\
\hline Agroforestry & $15 \cdot 22$ & $6 \cdot 18$ & $2 \cdot 16$ & $1 \cdot 33$ & $1 \cdot 38$ & $26 \cdot 27$ \\
\hline Pasture & $2 \cdot 54$ & $7 \cdot 09$ & $2 \cdot 51$ & 1.73 & 1.67 & $15 \cdot 54$ \\
\hline Total (\%) & $70 \cdot 11$ & $16 \cdot 74$ & $5 \cdot 85$ & 3.77 & 3.51 & \\
\hline
\end{tabular}

spatial resolution. The use of GIS provides the tools to manage and analyze these data. However, the evaluation of these data is necessary before they are used. The uncertainties regarding data sources may introduce larger uncertainties in soil erosion estimates. Great attention should be paid to the evaluation and preprocessing of data sources, such as data interpolation, conversion, and registration. 
Estimation of soil erosion loss in a large area is often difficult, as well as its validation. Although this paper focuses on the evaluation of soil erosion risk, validation using reference data is also valuable. For example, if reference data are available, the classification of soil erosion risk and the identification of thresholds for each risk level will be more appropriate.

In summary, this study provides an approach for the evaluation of soil erosion risk in Brazilian Amazonia based on a combination of RUSLE, remote sensing, and GIS. This is an effective way to map the spatial distribution of soil erosion risks in a large area. The methods and results described in this article are valuable for understanding the relationship between soil erosion risk and LULC classes and are useful for managing and planning land use that will avoid land degradation. For Brazilian Amazonia, such topics are very important due to current activities involving forest conversion to other land covers.

\section{ACKNOWLEDGEMENTS}

The authors wish to thank the National Science Foundation (grants 95-21918 and 99-06826), the National Aeronautics and Space Administration (grant N005-334), and Embrapa Satellite Monitoring for their support, which provided funds for the research that led to this article. This research is part of the Large-Scale BiosphereAtmosphere Experiment in Amazonia (LBA) program, LC-09, which is examining the human and physical dimensions of land-use and land-cover change.

\section{REFERENCES}

Adinarayana J, Rao KG, Krishna NR, Venkatachalam P, Suri JK. 1999. A rule-based soil erosion model for a hilly catchment. Catena 37: 309-318.

Ananda J, Herath G. 2003. Soil erosion in developing countries: a socio-economic appraisal. Journal of Environmental Management 68: 343-353.

Angima SD, Stott DE, O’Neill MK, Ong CK, Weesies GA. 2003. Soil erosion prediction using RUSLE for central Kenyan highland conditions. Agriculture, Ecosystems, and Environment 97: 295-308.

Bartsch KP, van Miegroet H, Boettinger J, Dobrwolski JP. 2002. Using empirical erosion models and GIS to determine erosion risk at Camp Williams. Journal of Soil and Water Conservation 57: 29-37.

Batistella M. 2001. Landscape change and Land-Use/Land-Cover dynamics in Rondônia, Brazilian Amazonia. CIPEC Dissertation Series, No. 7. Center for the Study of Institutions, Population, and Environmental Change (CIPEC), Indiana University: Bloomington, Indiana.

Batistella M, Robeson S, Moran EF. 2003. Settlement design, forest fragmentation, and landscape change in Rondônia, Amazonia. Photogrammetric Engineering and Remote Sensing 69: 805-812.

Boggs G, Devonport C, Evans K, Puig P. 2001. GIS-based rapid assessment of erosion risk in a small catchment in the wet/dry tropics of Australia. Land Degradation \& Development 12: 417-434.

Bognola IA, Soares AF. 1999. Solos das 'glebas 01, 02, 03 e 06' do Município de Machadinho d'Oeste, RO. Pesquisa em Andamento, No. 10. Embrapa Monitoramento por Satélite: Campinas, Brazil, 7.

Cerri CEP, Dematte JAM, Ballester MVR, Martinelli LA, Victoria RL, Roose E. 2001. GIS erosion risk assessment of the Piracicaba River Basin, southeastern Brazil. Mapping Sciences and Remote Sensing 38: 157-171.

D'Ambrosio D, di Gregorio S, Gabriele S, Gaudio R. 2001. A cellular automata model for soil erosion by water. Physics and Chemistry of the Earth, Part B: Hydrology, Oceans and Atmosphere 26: 33-39.

Embrapa. 1999. Sistema brasileiro de classificação de solos. Centro Nacional de Pesquisa de Solos: Rio de Janeiro.

Fullen MA. 2003. Soil erosion and conservation in northern Europe. Progress in Physical Geography 27: 331-358.

Goovaerts P. 1999. Using elevation to aid the geostatistical mapping of rainfall erosivity. Catena 34: 227-242.

Hickey R. 2000. Slope angle and slope length solutions for GIS. Cartography 29: 1-8.

INPE. 2002. Monitoring of the Brazilian Amazonia Forest by Satellite 2000-2001. Instituto Nacional de Pesquisas Espaciais: Jose dos Campos, Brazil.

Lal R. 1998. Soil erosion impact on agronomic productivity and environment quality: critical reviews. Plant Sciences 17: 319-464.

Lal R. 2001. Soil degradation by erosion. Land Degradation \& Development 12: 519-539.

Lemos RC, Santos RD. 1996. Manual de descrição e coleta de solos no campo, 3rd edn. SBCS/Embrapa-CNPS: Campinas, Brazil.

Lu D, Moran E, Batistella M. 2003. Linear mixture model applied to Amazonian vegetation classification. Remote Sensing of Environment 87: 456-469.

Lu D, Mausel P, Batistella M, Moran E. 2004. Comparison of land-cover classification methods in the Brazilian Amazonia basin. Photogrammetric Engineering and Remote Sensing 70: 723-731.

Ma JW, Xue Y, Ma CF, Wang ZG. 2003. A data fusion approach for soil erosion monitoring in the Upper Yangtze River Basin of China based on Universal Soil Loss Equation (USLE) model. International Journal of Remote Sensing 24: 4777-4789.

Markham BL, Barker JL. 1987. Thematic mapper bandpass solar exoatmospheric irradiances. International Journal of Remote Sensing 8: $517-523$. 
Mati BM, Veihe A. 2001. Application of the USLE in a savannah environment: comparative experiences from east and west Africa. Singapore Journal of Tropical Geography 22: 138-155.

Mikhailova EA, Bryabt RB, Schwager SJ, Smith SD. 1997. Predicting rainfall erosivity in Honduras. Soil Science Society of America Journal 61: $273-279$.

Millward AA, Mersey JE. 1999. Adapting the RUSLE to model soil erosion potential in a mountainous tropical watershed. Catena 38: 109-129.

Moran EF. 1981. Developing the Amazonia. Indiana University Press: Bloomington, Indiana.

Nearing MA, Foster GR, Lane LJ, Finkner SC. 1989. A process-based soil erosion model for USDA-Water Erosion Prediction Project Technology. Transactions of the ASAE 32: 1587-1593.

Parysow P, Wang G, Gertner GZ, Anderson AB. 2003. Spatial uncertainty analysis for mapping soil erodibility based on joint sequential simulation. Catena 53: 65-78.

Renard KG, Fremund JR. 1994. Using monthly precipitation data to estimate the R-factor in the revised USLE. Journal of Hydrology 157: 287306.

Renard KG, Foster GR, Weesies GA, McCool DK, Yoder DC. 1997. Predicting Soil Erosion by Water: A Guide to Conservation Planning with the Revised Universal Soil Loss Equation (RUSLE). Handbook \#703. US Department of Agriculture: Washington, DC; 404.

Reusing M, Schneider T, Ammer U. 2000. Modeling soil erosion rates in the Ethiopian Highlands by integration of high resolution MOMS-02/ D2-stereo-data in a GIS. International Journal of Remote Sensing 21: 1885-1896.

Romken MJM. 1983. The soil erodibility factor: a perspective. Soil Erosion and Conservation 10: 445-461.

Rondônia. 1998. Diagnóstico Sócio-Econômico do Estado de Rondônia e Assistência Técnica para Formulação da Segunda Aproximação do Zoneamento Sócio-Econômico-Ecológico-Climatologia, Vol. 1. Governo de Rondônia/PLANAFLORO: Porto Velho, Brasil.

Shakesby RA, Coelho COA, Schnabel S, Keizer JJ, Clarke MA, Contador JFL, Walsh RPD, Fereira AJD, Doerr SH. 2002. A ranking methodology for assessing relative erosion risk and its application to Dehesas and Montados in Spain and Portugal. Land Degradation \& Development 13: 129-140.

Shen DY, Ma AN, Lin H, Nie XH, Mao SJ, Zhang B, Shi JJ. 2003. A new approach for simulating water erosion on hillslopes. International Journal of Remote Sensing 24: 2819-2835.

Soil Survey Staff. 1993. Soil Survey Manual. USDA-SCS Agriculture Handbook, Vol. 18. USDA Soil Conservation Service: Washington, DC.

Soil Survey Staff. 1997. National Soil Survey Handbook, Title 430-VI. USDA Natural Resources Conservation Service: Washington, DC.

Soil Survey Staff. 1998. Keys to Soil Taxonomy, 8th edn. USDA Natural Resources Conservation Service: Washington, DC.

Soil Survey Staff. 1999. Soil Taxonomy: A Basic System of Soil Classification for Making and Interpreting Soil Surveys. Agriculture Handbook 436. USDA Natural Resources Conservation Service: Washington, DC.

Thiam AK. 2003. The causes and spatial patterns of land degradation risk in southern Mauritania using multitemporal AHVRR-NDVI imagery and field data. Land Degradation \& Development 14: 133-142.

Valladares GS, Bognola IA, Gouvêa JRF. 2003. Levantamento de Reconhecimento de Solos de Média Intensidade da Gleba Machadinho, RO. Documentos 30. Embrapa Monitoramento por Satélite: Campinas, Brazil.

Van Remortel R, Hamilton M, Hickey R. 2001. Estimating the LS factor for RUSLE through iterative slope length processing of digital elevation data within ArcInfo Grid. Cartography 30: 27-35.

Veihe A, Rey J, Quinton JN, Strauss P, Sancho FM, Somarriba M. 2001. Modelling of event-based soil erosion in Costa Rica, Nicaragua and Mexico: evaluation of the EUROSEM model. Catena 44: 187-203.

Vrieling A, Sterk G, Beaulieu N. 2002. Erosion risk mapping: a methodological case study in the Colombian eastern plains. Journal of Soil and Water Conservation 57: 158-163.

Wang G, Gertner GZ, Liu X, Anderson A. 2001. Uncertainty assessment of soil erodibility factor for revised universal soil loss equation. Catena 46: 1-14.

Wang G, Gertner G, Singh V, Shinkareva S, Parysow P, Anderson A. 2002a. Spatial and temporal prediction and uncertainty of soil loss using the revized universal soil loss equation: a case study of the rainfall-runoff erosivity $R$ factor. Ecological Modeling 153: $143-155$.

Wang G, Wente S, Gertner GZ, Anderson A. 2002b. Improvement in mapping vegetation cover factor for the universal soil loss equation by geostatistical methods with Landsat Thametic Mapper images. International Journal of Remote Sensing 23: 3649-3667.

Wang G, Gertner G, Fang S, Anderson AB. 2003. Mapping multiple variables for predicting soil loss by geostatistical methods with TM images and a slope map. Photogrammetric Engineering and Remote Sensing 69: 889-898.

Wilson JP, Lorang MS. 2000. Spatial models of soil erosion and GIS. In Spatial Models and GIS: New Potential and New Models, Fotheringham AS, Wegener M (eds). Taylor \& Francis: Philadelphia, PA; 83-108.

Wischmeier WH, Smith DD. 1978. Predicting Rainfall Erosion Losses-A Guide to Conservation. Agricultural Handbook 537. US Department of Agriculture: Washington, DC. 